\title{
Preliminary Testing of SRAP Primers in Order to Establish Genetic Diversity of Astragalus exscapus L. subsp. transsilvanicus (Schur) Nyár.
}

\author{
Katalin $\mathrm{SZABO}^{1^{*}}$, Cristian Radu SISEA ${ }^{1^{*}}$, Rodica POP ${ }^{1)}$, Monica BODEA ${ }^{1)}$, Ioana Virginia \\ BERINDEAN ${ }^{11}$, Alexandru Sabin BĂDĂRĂU ${ }^{2)}$, Doru PAMFIL ${ }^{1)}$ \\ ${ }^{1}$ Faculty of Horticulture, University of Agricultural Sciences and Veterinary Medicine Cluj-Napoca, \\ Calea Manastur 3-5, 400372, Cluj-Napoca, Romania \\ ${ }^{2}$ Department of Geography, "Babes-Bolyai" University, Cluj-Napoca, Romania *) corresponding \\ author, e-mail: katalin.szabo@usamvcluj.ro; cristisisea@yahoo.com
}

BulletinUASVM Horticulture 72(1) / 2015

Print ISSN 1843-5254, Electronic ISSN 1843-5394

DOI:10.15835/buasvmcn-hort:11070

\begin{abstract}
The Carpathian List of Endangered Species contains eight Astragalus species mentioned to be vulnerable or endangered. One of them is the endemic Astragalus exscapus L. subsp. transsilvanicus (Schur) Nyár., a rare perennial plant with only 24 populations remaining in the Transylvanian basin. Analysis of genetic diversity and population structure of this threatened subspecies is an important prerequisite for its conservation. The present study investigates eight different populations of $A$. exscapus using sequence related amplified polymorphism (SRAP) molecular markers. This technique is a relatively new PCR-based system, more reliable than random amplified polymorphic DNA (RAPD) markers, and suitable for population structure analysis. This essay reports the screening of 64 SRAP primer combinations on 3 to 4 samples from every population with the aim of selecting the most reliable ones for subsequent analysis. PCR amplification products were assessed on $2 \%$ agarose gel and a total number of 1473 DNA fragments were visualized by EtBr staining. We selected fourteen primer combinations for further research based on clarity, reproducibility of amplified bands and high rates of polymorphism. The most efficient primer combination was Me8/Em3 which generated 42 visible DNA fragments.
\end{abstract}

Keywords: Astragalus exscapus, genetic diversity, primer testing, SRAP

\section{INTRODUCTION}

Astragalus exscapus L. is a rare melliferous perennial plant characterized by particularly narrow habitat requirements (Becker, 2010) and it is marked as vulnerable in the Carpathian List of Endangered Species (Witkowski, 2003). The subspecies transsilvanicus (Schur) Nyár. is localized in the Transylvanian basin (Podlech, 1988), with only 24 remaining populations. This local endemism, mapped by Bădărău et al. (2000, 2001), is considered to be of national interest, requiring strict protection in accordance with annex 4B of the Government Emergency Ordinance $57 / 2007$.

The main objective of our work is to assess the genetic diversity at molecular level and to find out the range of polymorphism within and between populations of $A$. exscapus in order to establish some conservation strategies. Molecular markers are commonly used in genetic diversity analysis, thereby our study will implement Sequencerelated amplified polymorphism (SRAP) markers. This technique is a relatively new PCR-based molecular marker system introduced by $\mathrm{Li}$ and Quiros (2001), presenting a higher reproducibility than RAPD and a simpler approach than AFLP. The preliminary testing of SRAP primers is a necessary step for selecting the most appropriate combinations in large-scale use of the specified technique, to characterize genetic diversity, which can help the establishment of more efficient conservation strategies. 


\section{MATERIALS AND METHODS}

Plant material was collected from 126 individuals belonging to eight natural populations of A. exscapus subsp. transsilvanicus (Table 1) situated in the Transylvanian basin. The obtained leaves were stored at $-20{ }^{\circ} \mathrm{C}$ until further processing. To find out the most suitable SRAP primer combinations we used four randomly selected samples (B13, G12, S11, V13).

Genomic DNA was isolated applying the CTAB method - as published by Pop et al. (2008). We optimized the protocol by using TissueLyser II - Qiagen for 30 seconds as an initial grinding stage with liquid nitrogen. The properties of the extracted DNA were determined using a NanoDrop1000 spectrophotometer.

The degree of polymorphism within and between populations is an important indicator in the survival potential of vulnerable species and it can be investigated by numerous techniques. SRAP molecular marker system ( $\mathrm{Li}$ and Quiros, 2001) specifically amplifies polymorphic junction fragments between exons and flanking DNA. For PCR reaction a specific forward and a reverse primer are employed, both consisting three elements: (1) an arbitrary filler sequence of 10 to 11 bases at the 5 ' end; (2) sequence motifs CCGG and AATT in the forward and reverse primer, respectively; (3) three selective bases at the 3' end. A special PCR running program was designed, that starts at $35{ }^{\circ} \mathrm{C}$ annealing temperature in the first five cycles, and then increases to $50{ }^{\circ} \mathrm{C}$ for the rest of the cycles. In order to select the most reliable primer combinations for further analysis of $A$. exscapus eight forward and eight 8 reverse primers were tested (Table 2).

Amplification for each of the 64 primer combinations was carried out on a Corbette Research PalmCycler. Every $15 \mu \mathrm{l}$ PCR reaction mix contained $1 \times$ Green Buffer, $1,5 \mathrm{mM} \mathrm{MgCl}, 200$ $\mu \mathrm{M}$ of dNTPs, $0,3 \mu \mathrm{M}$ of both forward and reverse primer, $1 \mathrm{U}$ of Taq DNA polymerase (Promega) and approximately $50 \mathrm{ng}$ of template DNA. After DNA amplification, the PCR products were electrophoresed on a $2 \%(\mathrm{w} / \mathrm{v})$ agarose gel, in 1.0 $\times$ TAE buffer, at $115 \mathrm{~V}$, for approximately 2 hours. The gel was stained in $1 \mu \mathrm{g} / \mathrm{mL} \mathrm{EtBr}$ for 20 to 30 minutes and photographed with Biospectrum AC.

Tab. 1.Geographical origins and sample size of eight natural populations of Astragalus exscapus L. subsp. transsilvanicus (Schur) Nyár.

\begin{tabular}{ccccc}
\hline Population code & Location & Sample size & Longitude E & Latitude N \\
\hline M & Milășel & 14 & $24^{\circ} 26^{\prime} 55.94^{\prime \prime}$ & $46^{\circ} 44^{\prime} 52.03^{\prime \prime}$ \\
B & Beleni & 15 & $23^{\circ} 51^{\prime} 52.38^{\prime \prime}$ & $46^{\circ} 45^{\prime} 57.65^{\prime \prime}$ \\
G & Gădălin & 19 & $23^{\circ} 50^{\prime} 50.40^{\prime \prime}$ & $46^{\circ} 51^{\prime} 28.38^{\prime \prime}$ \\
SI & Silivașu de campie & 15 & $24^{\circ} 17^{\prime} 4.08^{\prime \prime}$ & $46^{\circ} 46^{\prime} 41.58^{\prime \prime}$ \\
S & Săbed & 15 & $24^{\circ} 26^{\prime} 46^{\prime \prime}$ & $46^{\circ} 39^{\prime} 52^{\prime \prime}$ \\
V & Viișoara & 18 & $23^{\circ} 54^{\prime} 35^{\prime \prime}$ & $46^{\circ} 33^{\prime} 28^{\prime \prime}$ \\
SG & Sărmășel Gară & 15 & $24^{\circ} 12^{\prime} 45.04^{\prime \prime}$ & $46^{\circ} 47^{\prime} 3.11^{\prime \prime}$ \\
VF & Valea Florilor & 15 & $23^{\circ} 47^{\prime} 48.75^{\prime \prime}$ & $46^{\circ} 40^{\prime} 25.19^{\prime \prime}$ \\
\hline
\end{tabular}

Tab. 2.SRAP primers used in the present study

\begin{tabular}{cllll}
\hline No. & & Forward primers & & Reverse rpimers \\
\hline 1 & Me1 & TGA GTC CAA ACC GGA TA & Em1 & GAC TGC GTA CGA ATT AAT \\
2 & Me2 & TGA GTC CAA ACC GGA GC & Em2 & GAC TGC GTA CGA ATT TGC \\
3 & Me3 & TGA GTC CAA ACC GGA AT & Em3 & GAC TGC GTA CGA ATT GAC \\
4 & Me4 & TGA GTC CAA ACC GGA CC & Em4 & GAC TGC GTA CGA ATT TGA \\
5 & Me5 & TGA GTC CAA ACC GGA AG & Em5 & GAC TGC GTA CGA ATT AAC \\
6 & Me6 & TGA GTC CAA ACC GGA CA & Em6 & GAC TGC GTA CGA ATT GCA \\
7 & Me7 & TGA GTC CAA ACC GGA CG & Em7 & GAC TGC GTA CGA ATT CAA \\
8 & Me8 & TGA GTC CAA ACC GGA CT & Em8 & GAC TGC GTA CGA ATT CAC \\
\hline
\end{tabular}




\section{RESULTS AND DISCUSSION}

The 64 combinations of the eight forward and eight reverse primers generated over 200 electrophoretic profiles. The images (Figure 1) were processed with Total Lab 120 software.

The main criteria by which the primer selection was made are: clarity, reproducibility of amplified bands and high rates of polymorphism. For example, lane-group 33 and 34 are similar - if we consider the number of generated bands - but lane 34 is more polymorphic than lane 33. In this case, we decided to continue working with the primers that generated higher rates of

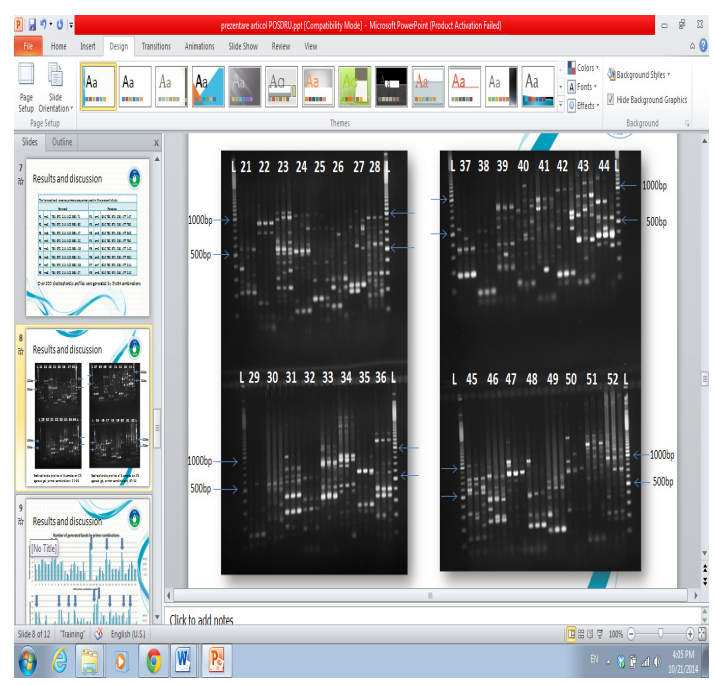

Electrophoretic profiles of 3 samples on $2 \%$ agarose gel; primer combinations 37-52

Fig. 1. Representative PCR amplification products with 32 different primer pair combinations.

Tab. 3. The 14 combinations selected

\begin{tabular}{ccccc}
\hline & \multicolumn{4}{c}{} \\
\hline \multirow{2}{*}{$\begin{array}{c}\text { Primer } \\
\text { combination }\end{array}$} & B3 & G12 & S11 & $\begin{array}{c}\text { Total } \\
\text { generated } \\
\text { bands }\end{array}$ \\
\cline { 2 - 5 } Me1/Em6 & 9 & 12 & 9 & 30 \\
\hline Me2/Em1 & 10 & 10 & 11 & 31 \\
\hline Me2/Em6 & 12 & 8 & 9 & 29 \\
\hline Me3/Em3 & 7 & 10 & 10 & 27 \\
\hline Me4/Em2 & 11 & 10 & 9 & 30 \\
\hline Me4/Em4 & 8 & 11 & 1 & 3 \\
\hline Me4/Em5 & 9 & 11 & 11 & 31 \\
\hline Me5/Em2 & 9 & 10 & 10 & 29 \\
\hline Me5/Em6 & 10 & 10 & 9 & 29 \\
\hline Me6/Em1 & 11 & 9 & 12 & 32 \\
\hline Me6/Em8 & 6 & 11 & 11 & 28 \\
\hline Me8/Em2 & 10 & 13 & 13 & 36 \\
\hline Me8/Em3 & 13 & 15 & 14 & 42 \\
\hline Me8/Em6 & 16 & 15 & 11 & 42 \\
\hline Total & 141 & 155 & 150 & 446 \\
\hline Average & 10.07 & 11.07 & 10.71 & 31.86 \\
\hline & & & & \\
\hline
\end{tabular}

Average

10.00

10.33

9.67

9.00

10.00

10.00

10.33

9.67

9.67

10.67

9.33

12.00

14.00

14.00

10.59 
polymorphism even if the produced bands are the same numerically in both situations.

To assure reproducibility of amplified bands, the basic steps were performed successfully in two repetitive experiments. After screening the PCR amplification products (1473 in total) for reproducibility and polymorphism, 50 combinations were discarded out of the 64 tested. The remaining 14 combinations produced total 446 DNA fragments with an average of 10.59 clear bands per primer combination.

\section{CONCLUSION}

The selected SRAP marker combinations represent a powerful tool to analyze genetic diversity in A. exscapus subsp. transsilvanicus. We are going to perform large-scale PCR amplification with the 14 primer combinations (Table 3) of SRAP markers on numerous individuals of the studied subspecies, in order to analyze genetic diversity and population structure. We expect that the revealed molecular diversity will help to design future conservation strategies concerning this endangered species.
Aknowledgement. This paper was published under the frame of European Social Fund, Human Resources Development Operational Programme 2007-2013, project no. POSDRU/159/1.5/S/ 132765 .

\section{REFERENCES}

1. Bădărău Al S, Dezsi St, Comes O (2000). Research biogeographical the steppe species of Astragalul L.silvostepice the Transylvanian depression, Studia universitatis Babes-Bolyai, Geographia, XLV, 2.

2. Bădărău Al S, Dezsi St, Man T ( 2001). Research biogeographical the steppe species of Astragalul L.silvostepice the Transylvanian depression (II), Studia universitatis Babes-Bolyai, Geographia, XLVI, 1.

3. Becker T (2010). Explaining Rarity of the Dry Grassland Perennial Astragalus exscapus , Folia Geobot 45:303-321.

4. Li G, Quiros CF (2001). Sequence-related amplified polymorphism (SRAP), A new marker system based on a simple PCR reaction: its application to mapping and gene tagging in Brassica, Theor. Appl. Genet., 103 p. 455-461.

5. Emergency Ordinance GEO no. 57/2007 on the regime of protected natural areas, conservation of natural habitats, wild flora and fauna published in the Official Gazette no. 442 of 29.6.2007.

6. Podlech D (1988). Revision von Astragalus L. sect. Caprini DC. (Leguminosae). Mitt Bot Staatssamml München 25:1924.

7. 7.Pop R (2008). Somaclonal variability study of grapevine using molecular markers, Editura Bioflux, Cluj-Napoca.

8. Witkowski ZJ, Król W, Solarz W (2003). Carpathian List Of Endangered Species, WWF and Institute of Nature Conservation, Polish Academy of Sciences, Vienna-Krako. 